DOI: 10.26693/jmbs03.06.304

UDC 579.61:58.072-082

Filimonova N. I. ${ }^{1}$, Gliebova K. V. $^{1}$, Shakun O. A. ${ }^{1}$, Tishchenko I. Y. ${ }^{1}$, Bosenko O. L.', Domarev A. P. ${ }^{2}$, Krichkovskaya L. V. ${ }^{2}$, Gorbach T. V.

\title{
ANTIMICROBIAL AND ANTIOXIDANT ACTIVITY OF ANTHOCYANIN COMPLEXES OF SOME BERRIES' SPECIES OF UKRAINE
}

\author{
${ }^{1}$ National University of Pharmacy, Kharkiv, Ukraine \\ ${ }^{2}$ National Technical University "Kharkiv Polytechnic Institute”, Ukraine \\ ${ }^{3}$ Kharkiv National Medical University, Ukraine
}

katerinaglebova25@gmail.com

The aim of the study was to determine the degree of antimicrobial activity of the anthocyanin complexes of Aronia melanocarpa (Aronia melanocarpa), black currant (Ribes nigrum), elderberry (Sambucus nigra) with reference culture Staphylococcus aureus ATCC 25923, Escherichia coli ATCC 25922, Bacillus subtilis ATCC 6633, Pseudomonas aeruginosa ATCC 27853, Candida albicans NCTC 885-653. The highest degree of microbiological sensitivity of bacterial cultures Staphylococcus aureus, Escherichia coli, Bacillus subtilis, Pseudomonas aeruginosa was observed in the native form of anthocyanin complexes derived from black currant (Ribes nigrum), Escherichia coli and Bacillus subtilis - to the anthocyanins in native form, derived from elder black (Sambucus nigra), which indicates their high antimicrobial activity against the microorganisms mentioned above. Reducing the concentration of anthocyanins in alcoholic extract at dilution in the ratio of $1: 1$ and $1: 2$ significantly decreased the microbiological sensitivity of microorganisms to them Staphylococcus aureus, Escherichia coli, Bacillus subtilis, Pseudomonas aeruginosa. When surveying the effects of anthocyanin complexes from Aronia melanocarpa, Ribes nigrum, Sambucus nigra on Candida albicans fungi culture, no sensitivity was established, which indicates the absence of antimycotic activity of the above complexes in laboratory conditions in vitro.

Keywords: anthocyanin complexes, antimicrobial activity, Aronia melanocarpa, Ribes nigrum, Sambucus nigra, Staphylococcus aureus, Escherichia coli, Bacillus subtilis, Pseudomonas aeruginosa, Candida albicans

Introduction. The evaluation of the effectiveness of the use of plant extracts in medicine as natural antioxidants and immunomodulators for the treatment of human diseases is a very relevant area of research [1-4]. Some recent studies of elongated herbs have indicated high levels of polyphenols, anthocyanins, quercetin and vitamin $\mathrm{C}$ that can exhibit antioxidant action. It is also known that anthocyanins have pronounced anticarcinogenic, antimicrobial and antiinflammatory effects and antidiabetic properties [5]. Plants of Ukrainian flora today are widely used in the treatment of various diseases, due to the high biological activity of their active substances, the absence of side effects and contraindications, which makes them irreplaceable in the treatment of cardiovascular, endocrine, cancer and other human pathologies [6-8]. Researchers are significantly interested in antimicrobial properties of flavonoids. Today mechanisms of influence of quercetin on gram-positive bacteria, flavonoids - on bacteria of the genus Staphylococcus, the antimicrobial action also have anthocyanins are well known [9, 10]. However, it should be noted that the antimicrobial properties of berry extracts (aronia, currants and elderberry) and their influence on specific microorganisms - human pathogens have not been sufficiently studied today. Also, the issues of the influence of antimicrobial substances, in particular, the anthocyanins of individual berries on the microflora of the gastrointestinal tract, on the growth and development of the organism, antioxidant properties, as well as the possibility of their use in the treatment of inflammatory processes, which determines the relevance of our research, remain unclear.

The Aim of the Study was to determine the degree of antimicrobial activity of the anthocyanin complexes of Aronia melanocarpa (Aronia melanocarpa), black currant (Ribes nigrum), elderberry (Sambucus nigra) with reference culture Staphylococcus aureus ATCC 25923, Escherichia coli ATCC 25922, Bacillus subtilis ATCC 6633, Pseudomonas aeruginosa ATCC 27853, Candida albicans NCTC 885-653.

Materials and Methods. The research was conducted at the Department of Microbiology, Virology and Immunology at the National University of 
Pharmacy (Kharkiv) in 2017. The object of the research was three experimental samples of the preparations of anthocyanin complexes, obtained from Aronia melanocarpa, black currant (Ribes nigrum), elderberry black (Sambucus nigra). Anthocyanin complexes (ACC) containing anthocyanidin glycosides were obtained by extraction (Rudakov et al., 2004). The determination of antimicrobial activity was carried out by diffusion method in the agar gel, according to the State Pharmacopoeia of Ukraine, in five replicates with each sample of ACC. According to World Health Organization recommendations, for the evaluation of the activity of the drugs, reference cultures of Staphylococcus aureus ATCC 25923, Escherichia coli ATCC 25922, Bacillus subtilis ATCC 6633, Pseudomonas aeruginosa ATCC 27853, Candida albicans NSTC 885-653 were used. The purity of each culture of the microorganism was confirmed by typical morphological, tinctorial, cultural and biochemical properties. Bacterial reference cultures were cultivated on meat-peptone agar at $37{ }^{\circ} \mathrm{C}$ for 24 hours, Candida fungi culture - on Saburo agar at $25{ }^{\circ} \mathrm{C}$ for 48 hours. During the study, suspensions of microbial cultures were made. For that, they washed away the microbial mass from the surface of the nutrient medium with a sterile suspending fluid containing $9 \mathrm{~g} / \mathrm{l}$ sodium chloride and $1.00 \mathrm{~g} / \mathrm{l}$ peptone. Microbial loading (according to McFarland standard) was 107 microbial cells per 1 $\mathrm{ml}$ of medium. 18-24 $\mathrm{h}$ culture of microorganisms and Mühler-Hinton agar were used in the work. Determination of antimicrobial activity was carried out by diffusion method in agar ("wells" method) on two layers of a solid nutrient medium in Petri dishes. In the lower layer, a "hungry" non-seeded medium was used, which is a $10 \mathrm{~mm}$ high substrate, on which 3 thinwalled cylinders made of stainless steel with a diameter of $8 \mathrm{~mm}$ and a height of $10 \mathrm{~mm}$ were mounted horizontally. Above the cylinders the upper layer of a nutritious agar medium (melted and cooled to $40{ }^{\circ} \mathrm{C}$, which was introduced by the standard of reference culture of the microorganism, was filled. The volume of the medium for the upper layer ranged from 14 to $16 \mathrm{ml}$. After cooling the agar, the cylinders were extracted with sterile tweezers and specimens of anthocyanine complexes in native form and in dilutions of $1: 2,1: 4$ in a sterile saline $\mathrm{NaCl}$ solution were placed into these wells. The cups were left for 30 minutes at room temperature, and then placed in a thermostat bacterial cultures at $37^{\circ} \mathrm{C}$ for 18-24 hours, a culture of yeast fungus at $25^{\circ} \mathrm{C}$ for 48 hours. After incubation, on the background of a uniform bacterial lawn, the presence or absence of a growth inhibition zone around the discs was evaluated. During the evaluation of the results, the following criteria were taken into account: absence of zones of inhibition of the growth of reference crops around the wells; zones of growth retardation of microorganisms up to $11 \mathrm{~mm}$ indicated the insensitivity of microorganisms to the drug introduced into the well; The growth retardation zones of reference cultures with a diameter of $11-15 \mathrm{~mm}$ indicated a low sensitivity of culture; zones with a diameter of $15-25 \mathrm{~mm}$ were evaluated as an indicator of the average microorganism sensitivity to the drug; areas of growth inhibition of reference crops, which exceeded $25 \mathrm{~mm}$ - high sensitivity of microorganisms to ACC. The statistical analysis of the data was carried out with the help of the computer program Statsoft Statistica v. 10.0 The comparison of the obtained results of microbiological research was carried out according to the non-parametric Wilcoxon criterion with the definition of the median (Me) and percentile (25\%$75 \%), p<0,05$ [11]. An estimation of the integral value of the antioxidant activity of the experimental ACC was carried out by the potentiometric method: an electrochemical cell with platinum and chloride-silver electrodes, a differential voltmeter B2-34, a mediator system $\mathrm{K}_{3}[\mathrm{Fe}(\mathrm{CN})]_{6} / \mathrm{K}_{4}[\mathrm{Fe}(\mathrm{CN})]_{6}$, the analytical signal is the current in the oxidation of the molecules required for the recovery of $\mathrm{Fe}^{3+} \rightarrow \mathrm{Fe}^{2+}$ ions by the extract of the anthocyanine complex. According to the results of the analysis of anthocyanins by the method of high-performance liquid chromatography and chromatographic mass spectrometry, the main components of the extracts are various anthocyanic glycosides [12-15]. Standard samples - solutions of gallic acid, analysed the changes in the potential of $\mathrm{Me}^{\mathrm{n}+}$ ox $/ \mathrm{Me}^{\mathrm{n}_{+}}$red from the galacic acid concentration as function $\mathrm{f}(\mathrm{mV})=\mathrm{C}$.

Results and Discussion. When examining antibacterial properties of anthocyanin complexes derived from black currants, black elder and aronia, it was found that in the native form ACC from black currant had the best antibacterial properties - the highest sensitivity was observed in all tested microorganisms. Escherichia coli and Bacillus subtilis had a high sensitivity to the ACC of the elderberry of the black and blue-green aronia, and Staphylococcus aureus and Pseudomonas aeruginosa - a moderate sensitivity (Table).

In the dilution of $1: 1$, a high sensitivity of black currant to ACC was observed only in Bacillus subtilis, the rest microorganisms had a moderate sensitivity. Staphylococcus aureus, Pseudomonas aeruginosa and Bacillus subtilis had a medium sensitivity to ACC from elderberry black, E. coli had low-sensitivity. Bacillus subtilis infectious culture had an average sensitivity to the ACC from aronia, a culture of Staphylococcus aureus was insensitive. In the dilution 1:2, the average sensitivity to ACC of black currant and elderberry black was observed only in B. subtilis. The 


\section{Біологічні науки}

Table - Results of study of antimicrobial and antioxidant activity plant's anthocyanin complexes (Me, 25\%-75\%)

\begin{tabular}{|c|c|c|c|c|c|c|}
\hline $\begin{array}{l}\text { Anthocyanin } \\
\text { complexes }\end{array}$ & Concentration & $\begin{array}{c}\text { Staphylococcus } \\
\text { aureus }\end{array}$ & Escherichia coli & $\begin{array}{c}\text { Pseudomonas } \\
\text { aeruginosa }\end{array}$ & Bacillus subtilis & $\begin{array}{c}\text { Antioxidant } \\
\text { activity, } \mathrm{mg} / \mathrm{g}\end{array}$ \\
\hline \multirow{3}{*}{$\begin{array}{l}\text { Ribes } \\
\text { nigrum }\end{array}$} & $\begin{array}{l}\text { Native } \\
\text { form }\end{array}$ & $\begin{array}{c}27.00^{*} \\
27.00-28.00\end{array}$ & $\begin{array}{c}36,00^{*} \\
35,0-37,0\end{array}$ & $\begin{array}{c}27.00^{*} \\
26.00-28.00\end{array}$ & $\begin{array}{c}31.00^{*} \\
30.00-32.0\end{array}$ & \multirow{3}{*}{4,42} \\
\hline & $1: 1$ & $\begin{array}{c}20.00^{* *} \\
19.00-22.00\end{array}$ & $\begin{array}{c}17.00^{* *} \\
16.00-18.00\end{array}$ & $\begin{array}{c}23.00^{* *} \\
22.00-24.00\end{array}$ & $\begin{array}{c}25.00^{*} \\
25.00-27.00\end{array}$ & \\
\hline & $1: 2$ & 0 & 0 & 0 & $\begin{array}{c}21.00^{\star *} \\
21.00-22.00\end{array}$ & \\
\hline \multirow{3}{*}{$\begin{array}{l}\text { Sambucus } \\
\text { nigra }\end{array}$} & $\begin{array}{c}\text { Native } \\
\text { form }\end{array}$ & $\begin{array}{c}21.00^{* *} \\
20.00-22.00\end{array}$ & $\begin{array}{c}32.00^{*} \\
32.00-33.00\end{array}$ & $\begin{array}{c}24.00^{* *} \\
24.00-25.00\end{array}$ & $\begin{array}{c}31.00^{*} \\
30.00-32.00\end{array}$ & \multirow{3}{*}{4,21} \\
\hline & $1: 1$ & $\begin{array}{c}17.00^{* *} \\
16.00-19.00\end{array}$ & $\begin{array}{c}14.00^{* * *} \\
13.00-15.00\end{array}$ & $\begin{array}{c}18.00^{* *} \\
18.00-19.00\end{array}$ & $\begin{array}{c}23.00^{* *} \\
22.00-24.00\end{array}$ & \\
\hline & $1: 2$ & 0 & 0 & 0 & $\begin{array}{c}18.00^{* *} \\
17.00-18.00\end{array}$ & \\
\hline \multirow{3}{*}{$\begin{array}{c}\text { Aronia } \\
\text { melanocarpa }\end{array}$} & $\begin{array}{l}\text { Native } \\
\text { form }\end{array}$ & $\begin{array}{c}22.00^{* *} \\
21.00-23.00\end{array}$ & $\begin{array}{c}34.00^{*} \\
33.00-35.00\end{array}$ & $\begin{array}{c}17.00^{\star *} \\
16.00-18.00\end{array}$ & $\begin{array}{c}29.00^{*} \\
29.00-31.00\end{array}$ & \multirow{3}{*}{4,36} \\
\hline & $1: 1$ & $\begin{array}{c}14.00^{* * *} \\
13.00-15.00\end{array}$ & 0 & 0 & $\begin{array}{c}20.00^{* \star} \\
19.00-21.00\end{array}$ & \\
\hline & $1: 2$ & 0 & 0 & 0 & 0 & \\
\hline
\end{tabular}

Notes: ${ }^{*}$ - high sensitivity $(>25 \mathrm{~mm}) ;{ }^{* *}-$ average sensitivity $(15-25 \mathrm{~mm}) ;{ }^{* * *}-$ low sensitivity $(11-15 \mathrm{~mm}) ; 0-$ no sensitivity.

mechanism of action of ACC on microorganisms, obviously, is aimed at the destruction of cell walls and inhibition of nutrition of microbial cells. When investigating sensitivity to ACC from Candida albicans fungi, their antimycotic effect in vitro was not established. The mechanisms underlying the anthocyanin activity include both the membrane and intracellular interactions of these compounds. The antimicrobial activity of anthocyanins contained in fruits is most likely due to multiple mechanisms and synergies, since they contain various compounds, including anthocyanins, weak organic acids, phenolic acids and mixtures of different chemical forms. Today the antimicrobial activity of crude extracts of phenolic compounds of various fruits (mainly berries) against human pathogens is extensively studied, however, there is lack of information about the antimicrobial activity of pure anthocyanins. As a rule, anthocyanins are active against different microbes, however gram-positive bacteria are usually more susceptible to the action of anthocyanin than gram-negative bacteria. A general study demonstrates the potential of anthocyanin extracts as natural alternative effective antimicrobial agents. In addition, the ability of the extract to reduce adhesion without reducing bacterial growth declines the probability of developing resistance while reducing the likelihood of infection. In assessing the antimicrobial properties of anthocyanins contained in the extract of Viburnum opulus fruits, there has been a significant inhibition of the growth of a wide range of human pathogenic bacteria, both gram-negative (Salmonella typhimurium and Salmonella agona) and Gram- positive (Staphylococcus aureus, Lysteria monocytogenes and Enterococcus faecalis). In contrast, the yeasts of Debaryomyces hansenii and Torulaspora delbrueckii have shown a complete resistance to anthocyanins of the fruit of the Kalina, whereas their low sensitivity was demonstrated in Trichosporon cutaneum, Kluyveromyces marxianus, Saccharomyces cerevisiae, Saccharomyces cerevisiae $12 R$ and Candida parapsilosis [16].

A number of authors noted that blueberry contains a significant amount of flavonoids, with which a number of beneficial effects for human health are associated. The effect of the extract of bilberry (Vaccinium angustifolium) on two major etiological components periodontitis, multifactorial disorders affecting the supporting structure of the teeth was studied. Phenolic acids, flavonoids (flavonols, anthocyanins) and procyanidins accounted for 16.6 and $12.9 \%$ of blueberry extract, respectively. Bilberry extract showed its antibacterial activity (minimal inhibitory concentration $1 \mathrm{mg} / \mathrm{ml}$ ) against the parodontopathogenic bacterium Fusobacterium nucleatum (Gram-negative anaerobic non-spore-forming bacteria). Also, the blueberry extract at $62.5 \mu \mathrm{g} / \mathrm{ml}$ inhibited the formation of Fusobacterium nucleatum biofilm by $87.5 \pm 2.3 \%$. Also, it has been found by the authors that there is an inflammatory action bilberry extract. This double antibacterial and anti-inflammatory effect of bilberry polyphenols suggests that it can be a promising candidate for new therapeutic agents [17].

Often, urinary tract infection is a major problem for elderly people, and the basis for treatment is antibiotics. 
The increasing prevalence of bacteria that cause urological disorders, resistant to antimicrobial agents, has stimulated interest in specific nutrients, such as cranberries, to prevent recurrence of urinary tract infections. Chokeberry (Aronia melanocarpa) is a rich source of phenolic substances, and thus, the dietary intake of black juice of black chokeberry can reduce the number of urinary tract infections requiring treatment. The authors have suggested daily use of juice of black chokeberry with a high content of total phenols (715 mg of gallic acid equivalent, $100 \mathrm{ml}(-1)$ ), including B-type procyanidins, anthocyanins and chlorogenic acids. The results have not revealed an immediate decrease in the incidence of urinary tract infections or the general use of antibiotics. However, during the subsequent 3-month period of administration of juice in the groups, a decrease in the doses of antibiotics to $55 \%$ in relation to pathogens of the urinary tract was observed [18]. It is known that species of wild berries exhibit a wide range of pharmacological actions. They have long been traditionally used for antiseptic, antimicrobial, cardioprotective and antioxidant properties. The authors have also investigated the potential of selective antiviral activity of common methanol extracts, as well as anthocyanins and nonanthocyanins from certain berries: strawberries (Fragaria vesca) and raspberries (Rubus idaeus) of Rosaceae family, bilberry (Vaccinium myrtillis) and cowberry (Vaccinium vitis-idaea) Ericaceae. The antiviral effect was tested against viruses of families $P i$ cornaviridae, Paramyxoviridae, Orthomyxoviridae, pathogenic for humans, in which chemotherapy and chemoprophylaxis is indicated. The results have shown that the extracts tested for all berries inhibit the replication of the virus CV-B1 (Picornaviridae) and influenza A (Orthomyxoviridae). CV-B1 is most inhibited by both blueberries and strawberries, and also extracts of magnolia vine, and influenza A - by extracts of blueberries and strawberries. The anthocyanin fractions of all wild berries significantly inhibit the replication of the A / H3N2 influenza virus, therefore some wild berries can be a valuable resource of antiviral substances [19]. A number of authors studied the antimicrobial properties of anthocyanins of blueberry (Vaccinium angustifolium) against Escherichia coli O157: H7, Listeria monocytogenes, Salmonella Typhi- murium and Lactobacillus rhamnosus. It has been established that blueberry anthocyanins suppress the growth of intestinal pathogens and do not affect the probiotic L. Rhamnosus [20]. We have established the antibacterial properties of ACC from the black currant against Escherichia coli, Bacillus subtilis, Staphylococcus aureus and Pseudomonas aeruginosa. The study has found that there is a significant inhibition of the growth of the studied organisms. Escherichia coli and Bacillus subtilis have shown a high sensitivity to ACC, Staphylococcus aureus and Pseudomonas aeruginosa have shown a middle one. In the study of sensitivity to ACC from Candida albicans fungi, their antimycotic effect in vitro was not established.

\section{Conclusions}

1. The highest degree of microbiological sensitivity of bacterial cultures Staphylococcus aureus, Escherichia coli, Bacillus subtilis, Pseudomonas aeruginosa, derived from black currant (Ribes nigrum), was observed to anthocyanin complexes in the native form; Escherichia coli and Bacillus subtilis, obtained from elder black (Sambucus nigra) to the anthocyanin complexes in native form. It indicates their high antimicrobial activity against the microorganisms mentioned above.

2. The decrease in the concentration of anthocyanin complexes in the alcohol extract at dilution in the ratio of $1: 1$ and $1: 2$ significantly reduced microbiological sensitivity to these microorganisms of Staphylococcus aureus, Escherichia coli, Bacillus subtilis, Pseudomonas aeruginosa.

3. In the study of the effects of anthocyanin complexes from Aronia melanocarpa, Ribes nigrum, Sambucus nigra on Candida albicans fungi culture, no sensitivity was established, which indicates the absence of antimycotic activity of the above complexes in laboratory conditions in vitro.

4. Anthocyanin complexes obtained from Aronia melanocarpa, Ribes nigrum, Sambucus nigra are complex according to the chemical composition of the compound for which the integral value of antioxidant activity extracts of the samples under study is a quantitative estimate of the total content of the bioflavanoid that determines their antimicrobial activity in vitro.

Prospects for Further Research. The authors have plans to study the antimicrobial activity of anthocyan complexes of other berries in Ukraine.

\section{References}

1. Borodina TN, Rumsh LD, Kunizhev SM, Sukhorukov GB, Vorozhtsov GN, Fel'dman BM, et al. Vklyucheniye ekstraktov lekarstvennykh rasteniy $v$ biodegradiruyemyye mikrokapsuly [Entrapment of herbal extracts in biodegradable microcapsules]. Biomeditsinskaia Khimiia. 2007; 53(6): 662-71. [Russian]

2. Licciardi PV, Underwood JR. Plant-derived medicines: a novel class of immunological adjuvants. International Immunopharmacol. 2011; 11(3): 390-8. PMID: 21056709. doi: 10.1016/j.intimp.2010.10.014

3. Korepanov SV, Openko TG. Primeneniye lekarstvennykh rasteniy s immunomoduliruyushchimi svoystvami v onkologii [The medicinal plants with immunomodulating properties in oncology]. Rossiyskiy Bioterapevticheskiy Zhurnal. 2012; 4(11): 15-20. [Russian] 
4. Singh B, Sidiq T, Joshi, P, Jain SK, Lawaniya Y, Kichlu S, Khajuria A, Vishwakarma RA, Bharate SB. Antiinflammatory and immunomodulatory flavones from Actinocarya tibetica Benth. Natural Product Research. 2013; 27 (23), 2227-30. https://doi.org/10.1080/14786419.2013.805334

5. Zulfugarova MB, Novruzov EN. Sostav i soderzhaniye antotsianov plodov Sambucus Ebulus L. [Composition and content of anthocyanins of fruits Sambucus Ebulus L.]. Khimiya rastitel'nogo syr'ya. 2017; 1: 163-7. doi: 10.14258/ jcprm.2017011422 [Russian]

6. Barbaste M, Berké B, Dumas M, Soulet S, Delaunay JC, Castagnino C, Arnaudinaud V, Chèze C, Vercauteren J. Dietary antioxidants, peroxidation and cardiovascular risks. The Journal of Nutrition, Health \& Aging. 2002; 6(3): 20922. PMID: 11887247

7. Hou DX. Potential Mechanisms of Cancer Chemoprevention by Anthocyanins Current. Molecular Medicine. 2003; 3 : 149-59. PMID: 12630561. doi: 10.1155/S1110724304403040

8. Brewer MS. Natural antioxidants: sources, compounds, mechanisms of action, and potential applications. Comprehensive Reviews in Food Science and Food Safety. 2011; 10: 221-46. doi: 10.1111/j.1541-4337.2011.00156.x

9. Rauha JP, Remes S, Heinonen M, Hopia A, Kähkönen M, Kujala T, et al. Antimicrobial effects of Finnish plant extracts containing flavonoids and other phenolic compounds. International Journal of Food Microbiology. 2000; 56(1): 3-12. PMID: 10857921. doi: 10.1016/S0168-1605(00)00218-X

10. Proestos C, Chorianopoulos N, Nychas GJ, Komaitis M. RP-HPLC analysis of the phenolic compounds of plant extracts. Investigation of their antioxidant capacity and antimicrobial activity. Journal of Agricultural and Food Chemistry. 2005; 53(4): 1190-5. PMID: 15713039. doi: 10.1021/jf040083t

11. Glantz S. Mediko-biologicheskaya statistika [Medico-Biological Statistics]. Moskva: Praktika; 1998. 459 p. [Russian]

12. Slimestad R, Solheim H. Anthocyanins from black currants (Ribes nigrum L.). Journal of Agricultural and Food Chemistry. 2002; 50(11): 3228-31. PMID: 12009991. https://doi.org/10.1021/jf011581u

13. Rudakov $\mathrm{OB}$, Khairutdinova $A D$, Odin AP. Fraktsionnyy sostav antotsianovykh krasiteley iz rastitel'nykh ekstraktov $\mathrm{i}$ kontrol' nad nimi metodom vysokoeffektivnoy zhidkostnoy khromatografii (VEZHKH) [Fractional composition of anthocyanin dyes from plant extracts and control over them by the method of high-performance liquid chromatography (HPLC)]. Vestnik Voronezhskogo gosudarstvennogo universiteta: seriya «Khimiya. Biologiya. Farmatsiya». 2004; 1, 85-93. [Russian]

14. Olas B, Wachowicz B, Nowak P, Kedzierska M, Tomczak A, Stochmal A, et al. Studies on antioxidant properties of polyphenol-rich extract from berries of aronia melanocarpa in blood platelets. Journal of physiology and pharmacology. 2008; 59: 823-35. PMID: 19212014

15. Veberic R, Jakopic J, Stampar F, Schmitzer V. European elderberry (Sambucus nigra L.) rich in sugars, organic acids, anthocyanins and selected polyphenols. Food Chemistry. 2009; 114: 511-5. https://doi.org/10.1016/ j.foodchem.2008.09.080

16. Cesonienè $L$, Daubaras $R$, Viškelis $P$, Sarkinas A. Determination of the total phenolic and anthocyanin contents and antimicrobial activity of Viburnum opulus fruit juice. Plant Foods for Human Nutrition. 2012; 67(3): 256-61. PMID: 22865031. doi: 10.1007/s11130-012-0303-3

17. Ben Lagha A, Dudonné S, Desjardins Y, Grenier D. Wild Blueberry (Vaccinium angustifolium Ait.) Polyphenols Target Fusobacterium nucleatum and the Host Inflammatory Response: Potential Innovative Molecules for Treating Periodontal Diseases. Journal of Agricultural and Food Chemistry. 2015; 63(31): 6999-7008. PMID: 26207764. doi: 10.1021/acs.jafc.5b01525

18. Handeland M, Grude N, Torp T, Slimestad R. Black chokeberry juice (Aronia melanocarpa) reduces incidences of urinary tract infection among nursing home residents in the long term - a pilot study. Nutrition Research (New York). 2014; 34(6): 518-25. PMID: 25026919. doi: 10.1016/j.nutres.2014.05.005

19. Nikolaeva-Glomb L, Mukova L, Nikolova N, Badjakov I, Dincheva I, Kondakova V, et al. In vitro antiviral activity of a series of wild berry fruit extracts against representatives of Picorna-, Orthomyxo- and Paramyxoviridae. Natural Product Communications. 2014; 9(1): 51-4. PMID: 24660461

20. Lacombe A, Wu VC, White J, Tadepalli S, Andre EE. The antimicrobial properties of the lowbush blueberry (Vaccinium angustifolium) fractional components against foodborne pathogens and the conservation of probiotic Lactobacillus rhamnosus. 2012; 30(1): 124-31. PMID: 22265292. doi: 10.1016/j.fm.2011.10.006

\section{УДК 579.61:58.072-082}

\section{АНТИМІКРОБНА ТА АНТИОКСИДАНТНА АКТИВНІСТЬ АНТОЦІАНОВИХ КОМПЛЕКСІВ ДЕЯКИХ ВИДІВ ЯГІД В УКРАЇНІ Філімонова Н. І., Глєбова К. В., Шакун О. А., Тіщенко І. Ю., Босенко О. Л., Домарьов А. П., Кричковська Л. В., Горбач Т. В.}

Резюме. У дослідженні розглянуто питання визначення ступеня антимікробної активності антоціанових комплексів Aronia melanocarpa (Aronia melanocarpa), чорної смородини (Ribes nigrum), бузини (Sambucus nigra) з еталонними культурами Staphylococcus aureus ATCC 25923, Escherichia coli ATCC 25922, Bacillus 
subtilis ATCC 6633, Pseudomonas aeruginosa ATCC 27853, Candida albicans NCTC 885-653. Найвищий ступінь мікробіологічної чутливості бактеріальних культур Staphylococcus aureus, Escherichia coli, Bacillus subtilis, Pseudomonas aeruginosa спостерігався в нативній формі антоціанових комплексів, отриманих 3 чорної смородини (Ribes nigrum), Escherichia coli та Bacillus subtilis - до антоціанів у натуральному вигляді, виділена з Sambucus nigra, що свідчить про високу антимікробну активність проти згаданих вище мікроорганізмів. Зниження концентрації антоціанів в спиртовому екстракті при розведенні у співвідношенні 1:1 та 1:2 значно знизило мікробіологічну чутливість мікроорганізмів до Staphylococcus aureus, Escherichia coli, Bacillus subtilis, Pseudomonas aeruginosa. При визначенні ефектів антоціанових комплексів з Aronia melanocarpa, Ribes nigrum, Sambucus nigra на культурі грибів Candida albicans не встановлено чутливості, що свідчить про відсутність антимікотичної активності антоціанів в лабораторних умовах in vitro.

Ключові слова: антоціанові комплекси, антимікробна активність, Aronia melanocarpa, Ribes nigrum, Sambucus nigra, Staphylococcus aureus, Escherichia coli, Bacillus subtilis, Pseudomonas aeruginosa, Candida albicans.

УДК 579.61: 58.072-082

\section{АНТИМИКРОБНАЯ И АНТИОКСИДАНТНАЯ АКТИВНОСТЬ АНТОЦИАНОВЫХ КОМПЛЕКСОВ НЕКОТОРЫХ ВИДОВ ЯГОД В УКРАИНЕ \\ Филимонова Н. И., Глебова Е. В., Шакун Е. А., Тищенко И. Ю.,}

\section{Босенко О. Л., Домарев А. П., Кричковская Л. В., Горбач Т. В.}

Резюме. В исследовании рассмотрен вопрос определения степени антимикробной активности антоциановых комплексов Aronia melanocarpa (Aronia melanocarpa), черной смородины (Ribes nigrum), бузины (Sambucus nigra) с эталонными культурами Staphylococcus aureus ATCC 25923, Escherichia coli ATCC 25922, Bacillus subtilis ATCC 6633, Pseudomonas aeruginosa ATCC 27853, Candida albicans NCTC 885-653. Высшая степень микробиологической чувствительности бактериальных культур Staphylococcus aureus, Escherichia coli, Bacillus subtilis, Pseudomonas aeruginosa наблюдалась в нативной форме антоциановых комплексов, полученных из черной смородины (Ribes nigrum), Escherichia coli и Bacillus subtilis - к антоцианам в натуральном виде, выделенная из Sambucus nigra, что свидетельствует о высокой антимикробной активностью против упомянутых выше микроорганизмов. Снижение концентрации антоцианов в спиртовом экстракте при разведении в соотношении 1: 1 и 1: 2 значительно снизило микробиологическую чувствительность микроорганизмов к Staphylococcus aureus, Escherichia coli, Bacillus subtilis, Pseudomonas aeruginosa. При исследовании эффектов антоциановых комплексов из Aronia melanocarpa, Ribes nigrum, Sambucus nigra на культуре грибов Candida albicans не установлено чувствительности, что свидетельствует об отсутствии антимикотической активности антоцианов в лабораторных условиях in vitro.

Ключевые слова: антоциановые комплексы, антимикробная активность, Aronia melanocarpa, Ribes nigrum, Sambucus nigra, Staphylococcus aureus, Escherichia coli, Bacillus subtilis, Pseudomonas aeruginosa, Candida albicans.

The authors of this study confirm that the research and publication of the results were not associated with any conflicts regarding commercial or financial relations, relations with organizations and/or individuals who may have been related to the study, and interrelations of coauthors of the article. 